\title{
Knockdown of 14-kDa phosphohistidine phosphatase expression suppresses lung cancer cell growth in vivo possibly through inhibition of NF- $\mathrm{kB}$ signaling pathway
}

\author{
A. XU ${ }^{1,3, *}, \mathrm{X} . \mathrm{LI}^{1,3}, \mathrm{~S} . \mathrm{WU}^{2}$, T. $\mathrm{LV}^{1}$, Q. JIN ${ }^{2}$, L. SUN ${ }^{4}, \mathrm{~J} . \mathrm{HUANG}^{1,3, *}$ \\ ${ }^{1}$ Experimental Center, Beijing Friendship Hospital, Capital Medical University, Beijing 100050, China; ${ }^{2}$ Clinical Laboratory Center, Beijing Friend- \\ ship Hospital, Capital Medical University, Beijing100050, China; ${ }^{3}$ National Clinical Research Center for Digestive Disease, Beijing Friendship \\ Hospital, Capital Medical University, Beijing 100050, China; ${ }^{4}$ Department of Pathology, Beijing Friendship Hospital, Capital Medical University, \\ Beijing100050, China
}

*Correspondence: huangj1966@hotmail.com,xuanjian1981@sina.com

Received November 28, 2015 / Accepted February 5, 2016

\begin{abstract}
In previous study, we reported that 14-kDa phosphohistidine phosphatase (PHP14) was associated with lung cancer cell migration and invasion. We also found that the expression of PHP14 was markedly increased in a part of human lung cancer tissues. In this study, we investigated the impact of PHP14 knockdown on lung cancer cell tumorigenesis in vitro and in vivo, as well as the regulatory pathway. Depletion of endogenous PHP14 expression in lung cancer cells reduced colony formation activity of lung cancer cells in vitro and inhibited the xenograft tumor growth in vivo. Further experiments revealed that the NF- $\kappa B$ signal pathway inhibitor PDTC inhibited the upregulated expression of MMP9 induced by PHP14 overexpression in lung cancer cells. Furthermore, knockdown of PHP14 in lung cancer cells correlated with decreased expression of a subset of NF- $\kappa \mathrm{B}$-regulated genes, such as BCL-2, COX-2, MCP-1, MMP9 and VEGF-C, which play an important role in tumor progression. Together these data suggest that knockdown of PHP14 in lung cancer cells inhibits lung cancer tumor growth in vivo, possibly via regulating the NF- $\mathrm{kB}$ pathway.
\end{abstract}

Key words: 14-kDa phosphohistidine phosphatase, NF- $\mathrm{B}$ signaling pathway, lung cancer, RNA interference

Lung cancer is the most common malignancy and the leading cause of cancer-related death worldwide [1]. Lung cancer development is a complex process involving the accumulation of genetic and epigenetic intreraction, resulting in uncontrolled proliferation, cellular transformation and the acquisition of aggressive behaviour [2]. Although much effort has been invested in identifying the genes involved in lung cancer, the mechanisms underlying this disease are not fully understood.

The 14-kDa phosphohistidine phosphatase (PHP14), also known as PHPT1, is the first histidine phosphatase protein identified in vertebrates and is similar to the janus proteins of Drosophila [3,4]. Several studies have demonstrated various physiological functions for PHP14, such as its ability to dephosphorylate ATP-citrate lyase [5] and the $\beta$-subunit of $G$ proteins in vitro [6]. A recent report also revealed that PHP14 could negatively regulate CD4 T cells through inhibition of the K channel KCa3.1 [7] and regulate the epithelial
$\mathrm{Ca}^{2+}$ channel TRPV5 by reversible histidine phosphorylation [8]. Some studies have revealed that histidine kinases and histidine phosphorylated proteins, such as Nm23, P-selectin, and annexin I, were associated with signal transduction in cancer $[9,10]$.

In our previous studies, we demonstrated that knockdown of PHP14 expression in lung cancer cells significantly inhibited lung cancer cell migration, invasion and metastasis in vitro and in vivo, and that the expression of PHP14 was higher in cancer patients with lymph node metastasis compared with patients without lymph node metastasis [11]. Further study found that the expression level of PHP14 was significantly higher in lung tumor samples (53.42\%) than normal tissues adjacent to tumor lesions (23.33\%) $(P=0.003)$ [12]. However, the roles of PHP14 in primary lung cancer growth and its mechanisms of action are still unknown. In this study, we examined the effect of PHP14 expression on lung cancer cell growth in vitro and in vivo, as well as the possible mechanism. 


\section{Materials and methods}

Cell lines. Non-small cell lung cancer cell line A549 and small cell lung cancer cell line NCI-H446 were originally obtained from the American Type Culture Collection (Rockville, $\mathrm{MD}$ ). Cells were cultured in Dulbecco's modified Eagle's medium (DMEM) (Gibco LifeBTechnologies, Gaithersburg, MD, USA), supplemented with 10\% FCS (HyClone, Logan, UT) at $37^{\circ} \mathrm{C}$ in $5 \% \mathrm{CO}_{2}$. U0126 was purchased from Cell Signaling Technology, pyrrolidinedithiocarbamate (PDTC) was purchased from Sigma-Aldrich. Mouse anti-human PHP14 polyclonal antibody and pcDNA3.1/PHP14 was generated as previous described [11].

RNA interference and stably transfected clone selection. As previously described [11], short interfering RNA (siRNA)coding oligos against human PHP14 targeting sequence CGGACATCTACGACAAAGT was cloned into pGPU6/GFP/ Neo siRNA expression vector. A siRNA oligo that did not match any known human coding CDNA was used as negative control. The insert-containing vector or control vector was stably transfected into A549 and H446 cells using the FuGENE 6 transfection reagent (Roche, Indianapolis, IN, USA). After 8 hours, cells were treated with $400 \mu \mathrm{g} / \mathrm{mL}$ G418-sulfate (G418, Merck). G418-sulfate-resistant clones were selected, and those clones were then expanded for further studies.

In vitro colony formation assay. To detect the anchorageindependent growth, six-well plates were precoated with $0.6 \%$ agarose in RPMI-1640 with 10\% FBS, and cells (A549 or H446) treated with siRNA were seeded at $1 \times 10^{3}$ cells per well in $0.3 \%$ agarose/ DMEM with 10\% FBS, respectively. The plates were incubated for 2 weeks. Colonies with a diameter greater than $100 \mu \mathrm{m}$ were counted under an inverted microscope.

Zymography assay. Gelatin zymography was used to determine the expression and activity of MMP2 and MMP9. Briefly, cells were seeded onto $100 \mathrm{~mm}$ plates using serum-free medium. After $24 \mathrm{~h}$, conditioned medium was collected, and protein concentrations were determined using the Bio-Rad protein assay (Bio-Rad, Hercules, CA, USA). Culture supernatants were subjected to electrophoresis on gelatin substrate gels (10\% SDS-polyacrylamide gels containing $1 \mathrm{mg} / \mathrm{mL}$ of gelatin). The gels were treated with $2.5 \%$ Triton X-100 for $30 \mathrm{~min}$ and incubated at $37^{\circ} \mathrm{C}$ for $24 \mathrm{~h}$ in a buffer containing $100 \mathrm{mM}$ Tris- $\mathrm{HCl}$ (pH 7.4), $0.15 \mathrm{M} \mathrm{NaCl}$, and $15 \mathrm{mM} \mathrm{CaCl}_{2}$. The gels were stained with Coomassie Blue R-250 and then de-stained with water until clear zones appeared.

RT-PCR. Total RNA was isolated from cell lines and tissues using Trizol reagent (Invitrogen, Carlsbad, CA), and $2 \mu \mathrm{g}$ was reverse transcribed into single-strand cDNA in $20 \mu \mathrm{L}$ of reaction buffer using Molony murine leukemia virus reverse transcriptase (Promega, Madison, WI) and oligo (dT)15 (Promega) as a primer. Specific primers of PHP14 were designed according to National Center for Biotechnology Information reference sequence, and $\beta$-actin was chosen as an internal control. The primers were used as follows: PHP14: sense: 5'-GCCACAGAGCCACCCCCA-3', antisense: 5'-ATCCAGACAAATCCTTCCAGCA-3'; $\beta$-actin: sense: 5'-GAGCTACGAGCTGCCTGACG-3', antisense: 5'CCTAGAAGCATTTGCGGTGG-3'. The RT-PCR primers of MMP9 are the same as the real time PCR primers. The PCR amplification was carried out in a reaction buffer containing $20 \mathrm{mM}$ Tris- $\mathrm{HCl}$ ( $\mathrm{pH} \mathrm{8.4),} 50 \mathrm{mM} \mathrm{KCl}, 1.5 \mathrm{mM} \mathrm{MgCl}_{2}$, all four dNTPs (each at $167 \mu \mathrm{M}$ ), $2.5 \mathrm{U}$ of Taq DNA polymerase, and $0.1 \mu \mathrm{M}$ primers. The reactions were performed in the ABI GeneAmp PCR System 9700 (Applied Biosystems, Foster City, CA) with the following program: denaturing for $30 \mathrm{sec}$ at $94^{\circ} \mathrm{C}$, annealing for $30 \mathrm{sec}$ at $60^{\circ} \mathrm{C}$, and elongating for $30 \mathrm{sec}$ at $72^{\circ} \mathrm{C}$ for a total of 25 cycles (for $\beta$-actin) or 27 cycles (for PHP14 and MMP9); the final extension took place at $72^{\circ} \mathrm{C}$ for 7 min. Equal volumes of each PCR sample were subjected to electrophoresis in a $1 \%$ agarose gel, which was then stained with ethidium bromide and photographed with Chemilmager 440 (Alpha Innotech Corp., San Leandro, CA).

Real time PCR. Primers of BCL-2, BCL-XL, COX-2, IL-8, IkBa, MCP-1, MMP2, MMP9, PHP14, TIMP1, TIMP2, uPA, VEGF-C and GAPDH used for quantitative PCR were designed using Primer 5 software (Table 1). The reactions were performed on the ABI 7500 Real-Time PCR System (Applied Biosystems) with SYBR ${ }^{\circledR}$ Green (Applied Biosystems). GAPDH was chosen as internal control. Each experiment was performed in $20 \mu \mathrm{l}$ of reaction volume containing $10 \mu \mathrm{S} \mathrm{SYBR}{ }^{\oplus}$

Table 1. Primers used for real-time PCR.

\begin{tabular}{|c|c|c|c|}
\hline Genes & & Primer sequences $\left(5^{\prime}-3^{\prime}\right)$ & $\begin{array}{c}\text { Product } \\
\text { sizes }\end{array}$ \\
\hline \multirow[t]{2}{*}{ BCL-2 } & Sense & GAGGATTGTGGCCTTCTTTG & $151 \mathrm{bp}$ \\
\hline & Anti-sense & CCCAGCCTCCGTTATCCT & \\
\hline \multirow[t]{2}{*}{ BCL-XL } & Sense & ACATCCCAGCTCCACATCAC & $174 \mathrm{bp}$ \\
\hline & Anti-sense & CGATCCGACTCACCAATACC & \\
\hline \multirow[t]{2}{*}{$\mathrm{COX}-2$} & Sense & TGCATTCTTTGCCCAGCACT & $144 \mathrm{bp}$ \\
\hline & Anti-sense & AAGGCGCAGTTTACGCTGTCT & \\
\hline \multirow[t]{2}{*}{ IL-8 } & Sense & ААСТТСТССАСААСССТС & $247 \mathrm{bp}$ \\
\hline & Anti-sense & TGGCAGCCTTCCTGATTT & \\
\hline \multirow[t]{2}{*}{$\mathrm{IkB} a$} & Sense & GTCAAGGAGCTGCAGGAGAT & $109 \mathrm{bp}$ \\
\hline & Anti-sense & ATGGCCAAGTGCAGGAAC & \\
\hline \multirow[t]{2}{*}{ MCP-1 } & Sense & TCTGTGCCTGCTGCTCATAG & $167 \mathrm{bp}$ \\
\hline & Anti-sense & GCTTCTTTGGGACACTTGCT & \\
\hline \multirow[t]{2}{*}{ MMP2 } & Sense & TGGCAAGTACGGCTTCTGTC & $179 b p$ \\
\hline & Anti-sense & TTCTTGTCGCGGTCGTAGTC & \\
\hline \multirow[t]{2}{*}{ MMP9 } & Sense & TGCGCTACCACCTCGAACTT & $200 \mathrm{bp}$ \\
\hline & Anti-sense & GATGCCATTGACGTCGTCCT & \\
\hline \multirow[t]{2}{*}{ PHP14 } & Sense & TCAGTAGCCGTCGTTAGCC & $174 \mathrm{bp}$ \\
\hline & Anti-sense & TGCGACTGTGAGTGTCTGGG & \\
\hline \multirow[t]{2}{*}{ TIMP1 } & Sense & CCGGGGCTTCACCAAGACCTA & $111 b p$ \\
\hline & Anti-sense & AGGTCCGTCCACAAGCAATGAGT & \\
\hline \multirow[t]{2}{*}{ TIMP2 } & Sense & AAGAGCCTGAACCACAGGTA & 175bp \\
\hline & Anti-sense & GAGCCGTCACTTCTCTTGAT & \\
\hline \multirow[t]{2}{*}{ uPA } & Sense & GCCTTGCTGAAGATCCGTTC & $91 \mathrm{bp}$ \\
\hline & Anti-sense & GGATCGTTATACATCGAGGGGCA & \\
\hline \multirow[t]{2}{*}{ VEGF-C } & Sense & CTACAGATGTGGGGGTTGCT & $240 \mathrm{bp}$ \\
\hline & Anti-sense & GCTGCCTGACACTGTGGTAA & \\
\hline \multirow[t]{2}{*}{ GAPDH } & Sense & GAGTCAACGGATTTGGTCGT & $185 \mathrm{bp}$ \\
\hline & Anti-sense & GACAAGCTTCCCGTTCTCAG & \\
\hline
\end{tabular}


Green PCR Master Mix (Applied Biosystems), $1 \mu \mathrm{l}$ of cDNA or $\mathrm{H}_{2} \mathrm{O}$ as negative control, $2 \mu \mathrm{l}$ of forward and reverse primers (Table $1,10 \mathrm{mM}$ each), and $7 \mu \mathrm{l}$ of distilled $\mathrm{H}_{2} \mathrm{O}$. Thermal cycle conditions for all the genes were as follows: $95^{\circ} \mathrm{C}$ for $10 \mathrm{~min}$, followed by $40 \mathrm{cycles}$ of $95^{\circ} \mathrm{C}$ for $30 \mathrm{sec}, 60^{\circ} \mathrm{C}$ for $1 \mathrm{~min}$. A uniform amplification of the products was rechecked by analyzing the melting curves of the amplified products. All reactions were carried out in triplicate to access the reproducibility. The relative quantitation of $\mathrm{mRNA}$ expression was calculated with the comparative $\mathrm{Ct}$ (the threshold cycle) method using the follow formula:

Ratio $=2^{-\Delta \Delta C t}=2^{-[\Delta C t(\text { sample })-\Delta C t(\text { calibrator })]}$, where $\Delta C t=C t$ of target genesof $-C t$ endogenous control gene (GAPDH) [13].

Western blot analysis. The cells were treated with lysis buffer [50 mM Tris- $\mathrm{HCl}$ pH8, $150 \mathrm{mM} \mathrm{NaCl}, 5 \mathrm{mM}$ ethylenediaminetetraacetic acid (EDTA), 1\% NP40 and a protease inhibitor cocktail (dissolve 1 tablet in $50 \mathrm{ml}$ lysis buffer)]. Equal quantities of protein were separated by $12 \%$ SDS-PAGE and transferred onto nitrocellulose membrane (Amersham Biosciences) using a Bio-Rad wet transfer unit. After blocking with $5 \%(\mathrm{w} / \mathrm{v})$ non-fat dried milk in TBST solution [25 mMTris, pH7.5, $150 \mathrm{mM} \mathrm{NaCl}, 0.05 \%$ ( v/v) Tween-20] for $1 \mathrm{hr}$ at room temperature, the membranes were incubated with mouse anti-human PHP14 polyclonal antibody (1:200 dilution) and rabbit anti-human $\alpha$-tubulin antibody $(1: 1000$, Santa Cruz Biotechnology) for $1 \mathrm{hr}$ at $37^{\circ} \mathrm{C}$ or overnight at $4^{\circ} \mathrm{C}$, followed by alkaline phosphatase-conjugated horse anti-mouse or goat anti-rabbit IgG (1:1000 dilution, Santa Cruz Biotechnology) for $1 \mathrm{~h}$ at $37^{\circ} \mathrm{C}$. Target proteins were detected by 5 -bromo-4chloro-3-indoyl phosphate (BCIP) and nitro blue tetrazolium (NBT). $\alpha$-tubulin was chosen as an internal control for equal protein loading.

Immunohistochemistry. The immunohistochemical staining of PHP14 was performed as previous [12]. Briefly, the slide was dried at $60^{\circ} \mathrm{C}$ for $4 \mathrm{~h}$, deparaffinized in xylene, and then rehydrated through a graded ethanol series. The endogenous peroxidase activity was blocked for 20 min with $3 \% \mathrm{H}_{2} \mathrm{O}_{2}$. Antigen retrieval was carried out in an antigen retrieval buffer $\left(10 \mathrm{mmol} / \mathrm{L}\right.$ citrated buffer $(\mathrm{pH} 6.0)$ ) at $95^{\circ} \mathrm{C}$ in a microwave cooker for 10 minutes.. After incubating the slide with bovine serum for $30 \mathrm{~min}$ at room temperature, the PHP14 antibody [1:50 dilution in PBST (PBS, 0.05\% Tween-20, pH 7.4)] was applied for one night at $4^{\circ} \mathrm{C}$ and then washed before incubated with the secondary antibody, HRP-conjugated, affinity purified donkey anti-mouse, for $1 \mathrm{~h}$ at $37^{\circ} \mathrm{C}$. Detection was performed with 3, 30-diaminobenzidine tetrahydrochloride peroxidase substrate and counterstaining with hematoxylin, followed by dehydration, clearing, and mounting.

Xenograft assay. Four to six weeks old female athymic nude mice were injected with tumor cells $\left(5 \times 10^{6}\right)$ subcutaneously into the left and right flank regions ( 5 mice per group). All animals were purchased from the Institute of Animal Science of the Vital River Co., Ltd. The animals had not received any drugs or previous procedures. Injected mice were examined every 3 or 5 days for tumor appearance, and tumor volumes were estimated from the length (a) and width (b) of the tumors, as measured by calipers, using the formula $\mathrm{V}=$ $\mathrm{ab}^{2} / 2$ [14]. Mice injected with cells derived from A549 cells carrying control-siRNA developed tumors approximately 9 days after inoculation, compared to 19 days of the group with A549 cells carrying PHP14-siRNA. Five mice per group were sacrificed 26 days after injection, and subcutaneous tumors were surgically excised, weighed, and photographed, and a portion of tumor was frozen at $-80^{\circ} \mathrm{C}$. All experiments and procedures involving mice were approved by an animal care and use committee at the Beijing Friendship Hospital, Capital Medical University. Our care and use of animals followed the guidelines of the Experimental Animal Management Ordinance.

Statistical analysis. We used SPSS software version 18.0 (SPSS INC., Chicago, IL, USA) to conduct all statistical comparisons. The data were presented as the mean $\pm \mathrm{SD}$. Mann-Whitney test was used to compare the differences between the control and experimental groups. All statistical tests were two sided. $P$ values of less than 0.05 were considered to be statistically significant.

\section{Results}

Inhibition of PHP14 expression in lung cancer cells suppresses anchorage-independent growth in vitro. To determine the function of PHP14 in cellular transformation, we first constructed an expression vector harboring PHP14 siRNA and stably transfected the PHP14 siRNA vector into A549 and H446 cells. As shown in Figure 1A and 1B, the mRNA and protein levels of PHP14 were significantly reduced in A549-siRNA and H446-siRNA cells compared with control cells harboring scramble siRNA $(p<0.05)$.

Anchorage-independent growth assay was performed to measure the effect of PHP14 knockdown on colony formation potential of lung cancer cells in vitro. Compared to cells transfected with control vector, cells with PHP14 knockdown showed significantly lower colony formation ability and produced smaller colonies $(p<0.05)$ (Figure 1C).

Knockdown of PHP14 expression in lung cancer cells inhibits xenograft tumor growth in vivo. To further explore the biological function of PHP14 in vivo, we generated tumor xenografts by subcutaneously inoculating tumor cells stably expressing PHP14 siRNA or control vector at the left and right flank regions of athymic nude mice. As shown in Figure 2A, comparison of the average tumor latency and volume revealed that tumors derived from A549 cells carrying PHP14 siRNA emerged later and proliferated to a smaller size compared to the control group. Moreover, the tumor incidence was also lower in the xenograft model (10/10 control, 7/10 PHP14 knockdown). The final weights of PHP14 knockdown tumors were significantly lower than controls (Figure 2B). However, the overall weight of mice did not show any differences among groups. Lungs of mice bearing xenograft tumors were also ex- 
amined but revealed no metastases in either control or PHP14 knockdown groups (data not shown). Semi-quantitative RT-PCR and immunohistochemistry of PHP14 in xenograft tumors confirmed that suppressed PHP14 expression had been maintained throughout the experimental time course (Figure 2C and D).

A

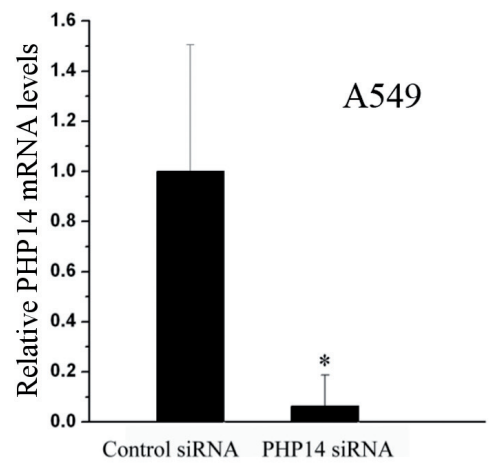

B

A549 Control siRNA PHP14siRNA

PHP14 (14 KDa) $\alpha$-tubulin (55 KDa)

\section{$\mathrm{C}$}

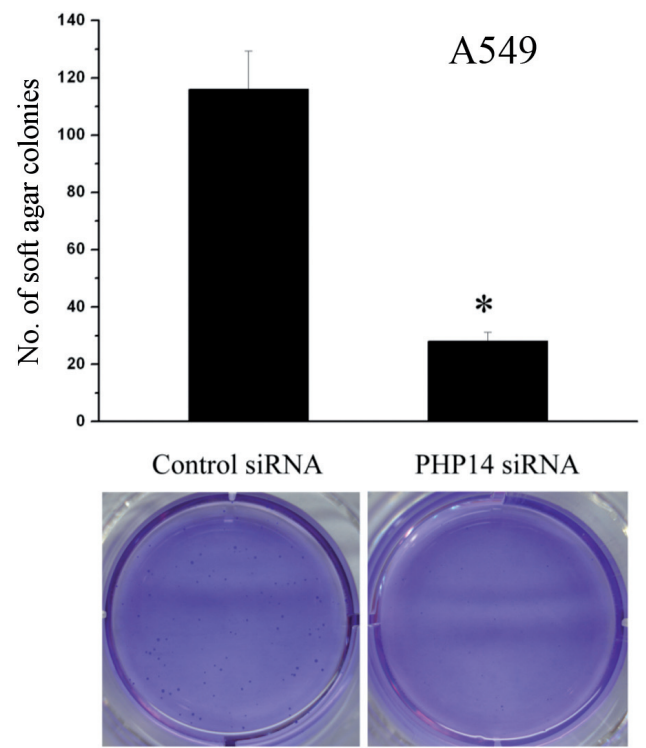

Depletion of endogenous PHP14 suppresses MMP expression in vitro. Matrix metalloproteinase (MMP)-2 and MMP9 are extracellular proteinases that contain fibronectin type II inserts within the catalytic domain and have implicated roles in tumorigenesis and metastasis [15]. We first examined the effect of PHP14 knockdown on MMP2 and MMP9 ex-

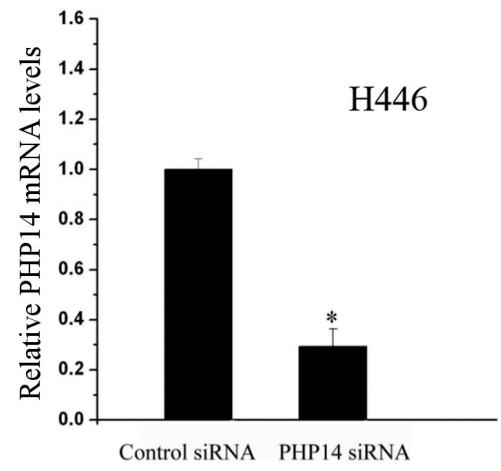

H446

Control siRNA PHP14 siRNA

PHP14 (14 KDa)

$\alpha$-tubulin (55 KDa)
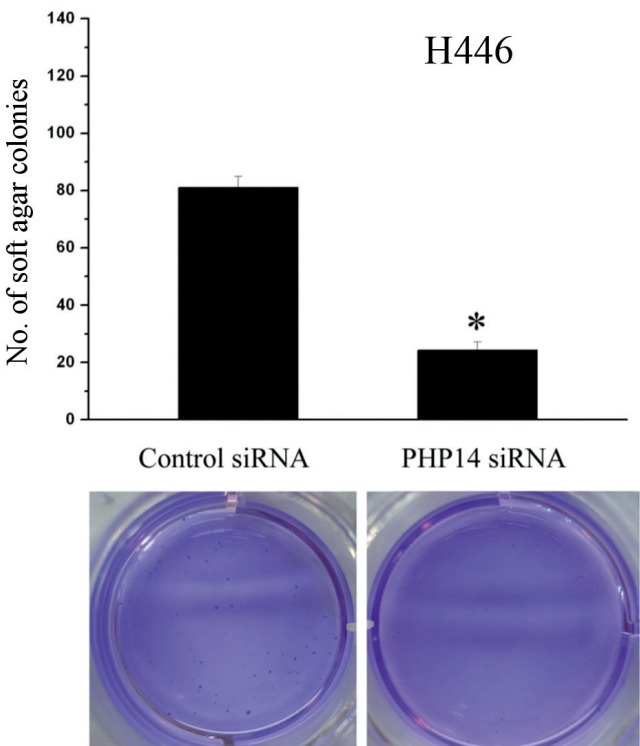

Figure 1. Knockdown of PHP14 expression by siRNA inhibited lung cancer cell colony formation. (A) Expression of PHP14 in A549 and H446 cells stably expressing control-siRNA or PHP14-siRNA as determined by quantitative PCR. GAPDH mRNA was used as an internal control. (B) Expression of PHP14 in A549 and H446 cells stably expressing control-siRNA or PHP14-siRNA as determined by western blot analysis. a-tubulin was used as an internal control. (C) Colony formation of A549 and H446 cells carrying control-siRNA or PHP14-siRNA as assessed by soft agar assay. Bottom, representative photos of soft agar colonies formed by cells carrying control-siRNA or PHP14-siRNA. Each data represents the mean \pm SEM value of triplicate wells. ${ }^{*} p<0.05$, Mann-Whitney test. 
A

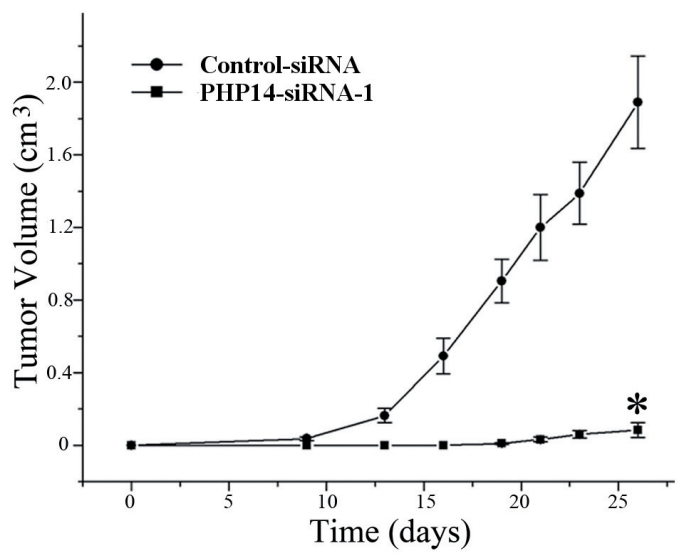

$\mathrm{C}$

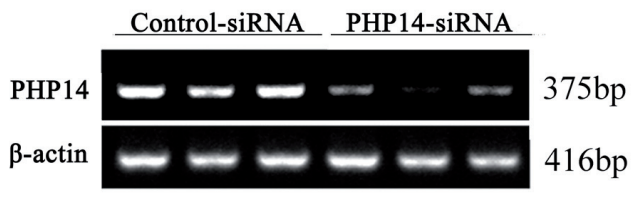

B
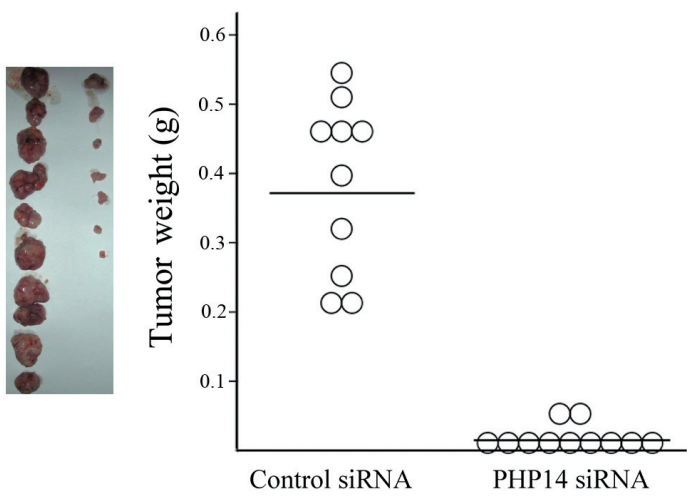

D

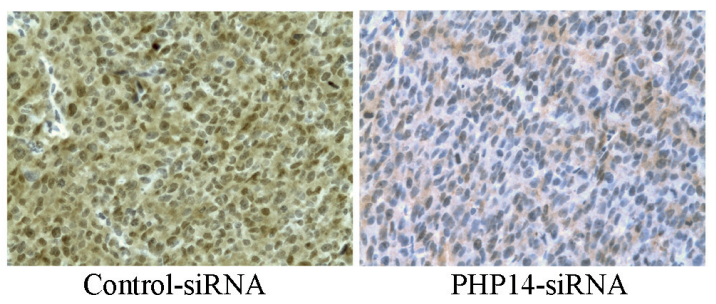

Figure 2. Knockdown of PHP14 expression in A549 cells inhibited xenograft tumor growth in vivo. (A) Volumes of tumors derived from control-siRNA (closed circle) or PHP14-siRNA (closed square) cells measured over time. Each data point represents the mean \pm SEM of ten xenograft tumors. (B) Xenograft tumors derived from control-siRNA or PHP14-siRNA at 26 days. Left, photographs of excised xenograft tumors. Right, weights of xenograft tumors. Tumors from two independent xenograft experiments were weighed immediately after removal. Mean xenograft tumor weight is indicated. (C) Expression of PHP14 mRNA was examined by semi-quantitative PCR of tumor cells from xenograft tumors of individual mice carrying either A549 control-siRNA tumors or A549 PHP14-siRNA tumors. $\beta$-actin was used as an internal control. (D) The expression of PHP14 in the primary tumors was examined by immunohistochemistry. ${ }^{\star} p<0.05$, log-rank statistical analysis.

pression and activity. MMP2 and MMP9 were significantly downregulated after PHP14 knockdown in A549 and H446 cells, while their inhibitors (TIMP1 and TIMP2) were upregulated. These results were confirmed by real time PCR (Figure 3A) and gelatin zymography assays (Figure 3B).

Table 2. PHP14 knockdown decreased expression of a subset of NF-kB regulated genes.

\begin{tabular}{lcccc}
\hline Cell line & \multicolumn{2}{c}{ A549 } & \multicolumn{2}{c}{ H446 } \\
\hline siRNA & Control & PHP14 & Control & PHP14 \\
\hline BCL-2 & $1 \pm 0.282$ & $0.231 \pm 0.178^{*}$ & $1 \pm 0.073$ & $0.186 \pm 0.075^{*}$ \\
BCL-XL & $1 \pm 0.053$ & $0.559 \pm 0.03$ & $1 \pm 0.069$ & $0.277 \pm 0.112^{*}$ \\
COX-2 & $1 \pm 0.174$ & $0.341 \pm 0.335^{*}$ & $1 \pm 0.074$ & $0.174 \pm 0.308^{*}$ \\
IkBa & $1 \pm 0.052$ & $0.924 \pm 0.037$ & $1 \pm 0.051$ & $0.841 \pm 0.072$ \\
IL-8 & $1 \pm 0.052$ & $1.437 \pm 0.029$ & $1 \pm 0.065$ & $0.145 \pm 0.143^{*}$ \\
MCP1 & $1 \pm 0.091$ & $0.256 \pm 0.301^{*}$ & $1 \pm 0.081$ & $0.234 \pm 0.272^{*}$ \\
MMP2 & $1 \pm 0.087$ & $1.022 \pm 0.213$ & $1 \pm 0.054$ & $0.074 \pm 0.072^{*}$ \\
MMP9 & $1 \pm 0.081$ & $0.428 \pm 0.377^{*}$ & $1 \pm 0.023$ & $0.093 \pm 1.059^{*}$ \\
uPA & $1 \pm 0.045$ & $1.119 \pm 0.027$ & $1 \pm 0.065$ & $0.63 \pm 0.264$ \\
VEGF-C & $1 \pm 0.136$ & $0.456 \pm 0.048^{*}$ & $1 \pm 0.038$ & $0.308 \pm 0.123^{*}$ \\
\hline
\end{tabular}

*: $p<0.05$, Mann-Whitney test.
Knockdown of PHP14 expression may inhibit lung cancer xenograft tumor growth through the NF- $\mathrm{kB}$ signal pathway. MMP2 and MMP9 are gelatinases secreted by different cell types $[15,16]$. The expression of MMPs is regulated by the MEK1 pathway and NF- $\kappa B$ pathway [17-19]. To investigate the pathway by which PHP14 regulates the expression of MMPs in lung cancer cells, PHP14-overexpressing A549 and H446 cells were treated with U0126 or PDTC, which selectively inhibit the MEK1 or NF- $\kappa$ B pathway, respectively. As shown in Figure 4, PHP14-overexpressing A549 and H446 cells showed increased MMP9 expression. The induction of MMP9 expression by PHP14 overexpression was not changed in the presence of MEK1 inhibitor U0126 (10 $\mu \mathrm{M}$ for $2 \mathrm{~h}$ ). However, the expression of MMP9 became undetectable in the presence of NF- $\kappa \mathrm{B}$ inhibitor PDTC (50 $\mu \mathrm{M}$ for $2 \mathrm{~h}$ ) regardless of PHP14 status, suggesting that PHP14 may affect lung cancer xenograft tumor growth and metastasis via NF- $\kappa \mathrm{B}$ pathway.

To confirm whether the NF- $\kappa \mathrm{B}$ pathway was regulated by PHP14, we examined the expression of $10 \mathrm{NF}-\kappa \mathrm{B}$ regulated genes in A549 siRNA and H446 siRNA cells using real time PCR. Besides the expression of IL- 8 and uPA genes, which were slightly increased in A549 siRNA cells, the expression of all other examined genes were decreased in siRNA cells (Table 2). 
A
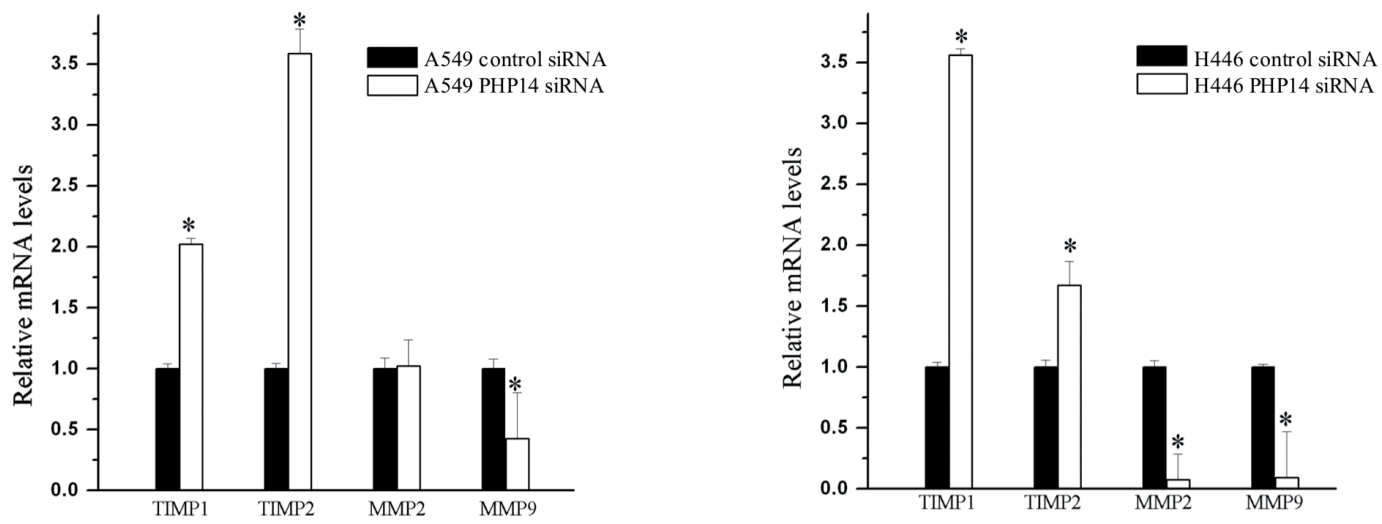

$\mathrm{B}$
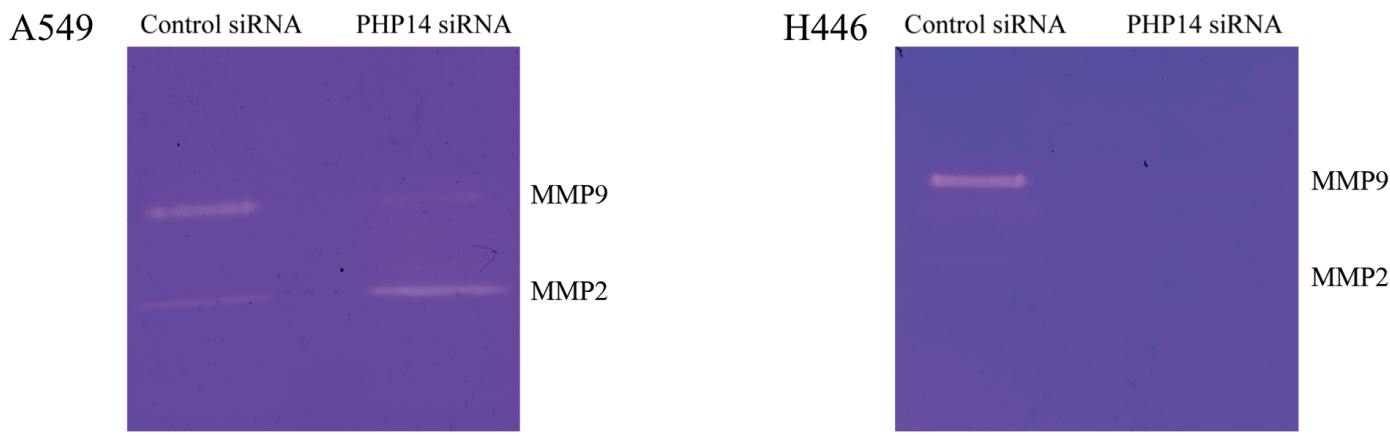

Figure 3. Depletion of endogenous PHP14 suppresses MMP expression in vitro. (A) Quantitative PCR analyses of TIMP1, TIMP2, MMP2, MMP9 in A549 and H446 cells carrying control-siRNA or PHP14-siRNA. (B) Levels of MMP-2 and MMP-9 in conditioned medium derived from siRNA-transfected A549 and $\mathrm{H} 446$ cells were determined by gelatin zymography. ${ }^{*} p<0.05$, Mann-Whitney test.

Five of ten genes were decreased more than 2-fold in A549 siRNA cells, while eight of ten genes were decreased more than 2-fold in H446 siRNA cells compared to control siRNA cells. These data confirm that NF- $\kappa B$ regulates these genes in a cell type-dependent manner [20]. Among the decreased genes, BCL-2, COX-2, MCP-1, MMP9 and VEGF-C were all downregulated in A549 and H446 siRNA cells.

\section{Discussion}

MMPs are the predominant extracellular proteolytic enzymes in mediating the interactions of extracellular matrix and tumor cells $[21,22]$. One of the earliest events in angiogenesis is basement membrane degradation, which requires MMP function [23]. MMP2 and MMP9 have been detected in malignant tissues and associated with tumor aggressiveness, angiogenesis and metastasis potential [24]. Our previous and present studies demonstrate that PHP14 can significantly affect lung cancer cell tumorigenesis and metastasis in vivo. To examine the mechanism underlying the effects of PHP14 knockdown, we evaluated the expression and activity of MMP2 and MMP9 in siRNA cells. This also provided a hint of the mechanism through which PHP14 affects lung cancer tumorigenesis and metastasis.
Multiple signaling transduction pathways are involved in the regulation of MMP production in human cancer cells. The expression of MMP9 is mostly regulated by the MEK1 and NF- $\kappa B$ pathways [24]. In our study, the upregulated expression

A549

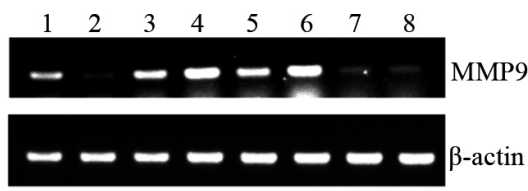

H446

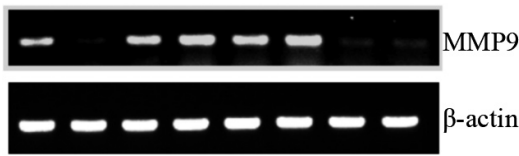

Figure 4. PHP14 may affect lung cancer xenograft tumor growth and metastasis via NF- $\mathrm{KB}$ pathway. PHP14-overexpressing A549 and $\mathrm{H} 446$ cells were treated with U0126 or PDTC, which selectively inhibit the MEK1 or NF- $\mathrm{KB}$ pathway, respectively, and MMP9 expression was detected. Lane 1, controlsiRNA cells; lane 2, PHP14-siRNA cells; lane 3, pcDNA3.1 transfected cells; lane 4, pcDNA3.1/PHP14 transfected cells; lane 5, pcDNA3.1 transfected cells treated with U0126; lane 6, pcDNA3.1/PHP14 transfected cells treated with U0126; lane 7, pcDNA3.1 transfected cells treated with PDTC; and lane 8, pcDNA3.1/PHP14 transfected cells treated with PDTC. 
of MMP9 in PHP14 overexpressing A549 and H446 cells was suppressed by the broad spectrum NF- $\mathrm{KB}$ inhibitor PDTC but not the MEK 1 inhibitor U0126, suggesting that PHP14 may regulate MMP9 expression via the NF- $\kappa \mathrm{B}$ pathway or that PHP14 may be a downstream gene of MEK1 to regulate the $\mathrm{NF}-\kappa \mathrm{B}$ pathway. The NF- $\mathrm{BB}$ pathway regulates the expression of a wide range of genes that are implicated in many normal and protective biological processes, but is also usurped during tumorigenesis. NF- $\mathrm{kB}$ pathway regulates critical processes related to cancer progression, including apoptosis, angiogenesis, invasion, metastasis, growth, and proliferation [25-26]. The NF- $\kappa \mathrm{B}$ pathway is regulated by many endogenous molecules and extracellular signals [27]. In our present study, knockdown of PHP14 inhibited the NF- $\mathrm{BB}$ pathway and downregulated the expression of many NF- $\mathrm{kB}$ regulated genes, such as BCL-2, COX-2, MCP-1, MMP9 and VEGF-C, both in A549 and H446 siRNA cells. Our data suggest that inhibition of PHP14 expression in lung cancer cells also inhibits the NF- $\mathrm{kB}$ pathway, which inhibits tumorigenesis and metastasis in vivo.

PHP14 is a protein histidine phosphatase. Histidine kinases and histidine phosphorylated proteins, such as $\mathrm{Nm} 23$, P-selectin, annexin I, have been found to play important roles in tumor growth and metastasis [10]. In our previous study, we found that knockdown of PHP14 expression in lung cancer cells inhibited cell migration and invasion both in vitro and in vivo [11], and the expression of PHP14 was significantly upregulated in lung cancer cells and tissues [12]. A recent report suggested that PHP14 might play an important role in hepatocellular carcinoma cell proliferation [28], but the mechanism was not fully elucidated. Here we show that knockdown of PHP14 expression also inhibits the lung cancer cell colony formation in vitro and xenograft tumor growth in vivo. Furthermore, we elucidate that PHP14 functions in lung cancer xenograft tumor growth and metastasis possibly via regulating the NF- $\mathrm{kB}$ pathway. Although our data show that the NF- $\kappa B$ pathway is regulated by PHP14, the functional relevance of PHP14 and NF- $\kappa \mathrm{B}$ is still unknown, and future studies will be focused on how PHP14 regulates NF- $\kappa \mathrm{B}$.

In conclusion, we demonstrate for the first time that knockdown of PHP14 in lung cancer cells inhibits lung cancer xenograft tumor growth and metastasis possibly via regulating the NF- $\kappa B$ pathway. The results of our study provide insight into a novel mechanism through which PHP14 plays a critical role in tumor progression.

Acknowledgements: This study was supported by a grant from the National Natural Science Foundation of China (no.81071973), and a grant from the Wang Bao-En Liver Fibrosis Foundation (grant no. 20100013)

\section{References}

[1] MOK TS, WU YL, THONGPRASERT FACSS, et al. Gefitinib orCarboplatin-Paclitaxel in pulmonaryadenocarcinoma.
N Engl J Med 2009; 361: 947-957. http://dx.doi.org/10.1056/ NEJMoa0810699

[2] BILD AH, YAO G, CHANG JT, WAND Q, POTTI A, et al. Oncogenic pathway signatures in human cancers as a guide to targeted therapies. Nature 2005; 439: 353-357. http://dx.doi. org/10.1038/nature04296

[3] EK P, PETTERSSON G, EK B, GONG F, LI JP, et al. Identification and characterization of a mammalian 14-kDa phos- phohistidine phosphatase. Eur J Biochem 2002; 269: 5016-5023. http://dx.doi. org/10.1046/j.1432-1033.2002.03206.x

[4] KLUMPP S, HERMESMEIER J, SELKE D, BAUMEISTER R, KELLNER R, et al. Protein histidine phosphatase: a novel enzyme with potency for neuronal signaling. J Cereb Blood Flow Metab 2002; 22: 1420-1424. http://dx.doi.org/10.1097/01. wcb.0000045041.03034.99

[5] KLUMPP S, BECHMANN G, MAURER A, SELKE D, KRIEGLSTEIN J. ATP-citrate lyase as a substrate of protein histidine phosphatase in vertebrates. Biochem Biophys Res Commun 2003; 306: 110-115. http://dx.doi.org/10.1016/ S0006-291X(03)00920-3

[6] MAURER A, WIELAND T, MEISSL F, NIROOMAND F, MEHRINGER R. The beta-subunit of G proteins is a substrate of protein histidine phosphatase. Biochem Biophys Res Commun 2005; 334: 1115-1120. http://dx.doi.org/10.1016/j. bbrc.2005.06.200

[7] SRIVASTAVA S, ZHDANOVA O, DI L, LI Z, ALBAQUMI $\mathrm{M}$, et al. Protein histidine phosphatase 1 negatively regulates CD4 T cells by inhibiting the $\mathrm{K}+$ channel KCa3.1. PNAS 2008; 105: 14442-14446. http://dx.doi.org/10.1073/ pnas.0803678105

[8] CAI X, SRIVASTAVA S, SURINDRAN S, LI Z, SKOLNIK EY. Regulation of the epithelial Ca2+ channel TRPV 5 by reversible histidine phosphorylation mediated by NDPK-B and PHPT1. Mol. Biol. Cell 2014; 25: 1244-1250. http://dx.doi.org/10.1091/ mbc.E13-04-0180

[9] KLUMPP S AND KRIEGLATEIN. Phosphorylation and dephos- phorylation of histidine residues in proteins. Eur J Biochem 2002; 269: 1067-1071. http://dx.doi.org/10.1046/ j.1432-1033.2002.02755.x

[10] STEEG PS, PALMIERI D, OUATAS T, SALERNO M. Histidine kinases and histidine phosphorylated proteins in mammalian cell biology, signal transduction and cancer. Cancer Lett 2003; 190: 1-12. http://dx.doi.org/10.1016/S03043835(02)00499-8

[11] XU AJ, HAO J, ZHANG Z, TIAN T, JIANG S, et al. 14 kDa phosphohistidine phosphatase and Its Role in Human Lung Cancer Cell Migration and Invasion. Lung Cancer 2010; 67: 48-56. http://dx.doi.org/10.1016/j.lungcan.2009.03.005

[12] XU AJ, XIA XH, DU ST, JUNCHAO G. Clinical significance of PHP14 in lung cancer. Chinese Medical Journal 2010; 123: 3247-3251.

[13] PFAFFL MW. A new mathematical model for relative quantification in real-time RT-PCR. Nucleic Acids Res. 2001; 29: 2002-2007. http://dx.doi.org/10.1093/nar/29.9.e45

[14] CONWAY TF, SABEL MS, SUGANO M, FRELINGER JG, EGILMEZ NK, et al. Growth of human tumor xenografts in SCID mice quantified using an immunoassay for tumor 
marker protein in serum. J Immunol Methods 2002; 233: 57-65. http://dx.doi.org/10.1016/S0022-1759(99)00190-8

[15] DERYUGINA EI, QUIGLEY JP. Tumor angiogenesis: MMP-mediated induction of intravasation- and metastasissustaining neovasculature. Matrix Biol. 2015; 44-46: 94-112. http://dx.doi.org/10.1016/j.matbio.2015.04.004

[16] BOND M, FABUNMI RP, AKER AH, NEWBY AC. Synergistic upregulation of metalloproteinase- 9 by growth factors and inflammatory cytokines: An absolute requirement for transcription factor NF-kB. FEBS Lett. 1998; 435, 29-34. http://dx.doi.org/10.1016/S0014-5793(98)01034-5

[17] VANDOOREN J, VAN DEN STEEN PE, OPDENAKKER G. Biochemistry and molecular biology of gelatinase $\mathrm{B}$ or matrix metalloproteinase-9 (MMP-9): the next decade. Crit Rev Biochem Mol Biol. 2013; 48: 222-272. http://dx.doi.org/10.3109/10 409238.2013.770819

[18] KIM H AND KOH G. Lipopolysaccharide activates matrix metalloproteinase-2 in endothelial cells through an NF-kBdependent pathway. Biochem. Biophys. Res. Commun. 2000; 269, 401-405. http://dx.doi.org/10.1006/bbrc.2000.2308

[19] TAKADA Y, ANDREEFF M, AGGARWAL BB. Indole-3carbinol suppresses NF-kB and IkBa kinase activation, causing inhibition of expression of NF-kB-regulated antiapoptotic and metastatic gene products and enhancement of apoptosis in myeloid and leukemia cells. Blood 2005; 106: 641-649. http:// dx.doi.org/10.1182/blood-2004-12-4589

[20] WANG J, AN H, MAYO MW, BALDWIN AS, YARBROUGH WG. LZAP, a Putative Tumor Suppressor, Selectively In- hibits NF-kB. Cancer Cell 2007; 12: 239-251. http://dx.doi. org/10.1016/j.ccr.2007.07.002

[21] VU TH, WERB Z. Matrix metalloproteinases: effectors of development and normal physiology. Genes Dev. 2000; 14: 2123-2133. http://dx.doi.org/10.1101/gad.815400

[22] KALEBIC T, GARBISA S, GLASER B, LiOTTA LA. Basement membrane collagen: degradation by migrating endothelial cells. Science 1983; 221: 281-283. http://dx.doi. org/10.1126/science.6190230

[23] RUNDHAUG JE. Matrix Metalloproteinases, Angiogenesis, and Cancer. Clin Cancer Res 2003; 9: 551-554.

[24] WEATERMARCK J, KAHARI VM:Regulation of matrix metalloproteinase expression in tumor invasion. FASEB J. 1999; 13: 781-792.

[25] HOBERT JE, YEUNG F AND MAYO MW. SMRT derepression by the IkB kinase a: A prerequisite to NF-kB transcription and survival. Mol. Cell 2004; 16: 245-255.

[26] KIM HJ, HAWKE N AND BALDWINN AS. NF-kB and IKK as therapeutic targets in cancer. Cell Death Differ. 2006; 13: 738-747. http://dx.doi.org/10.1038/sj.cdd.4401877

[27] POMERANTZ JL, BALTIMORE D. Two pathways to NF-B. Mol Cell 2002; 10: 693-695. http://dx.doi.org/10.1016/S10972765(02)00697-4

[28] HAN SX, WANG LJ, ZHAO J, ZHANG Y, LI M. 14 kDa Phosphohistidine phosphatase plays an important role in hepatocellular carcinoma cell proliferation. Oncol. Lett. 2012; 4: 658-664. 